\title{
Study on Reform of Accounting Education Mode of Higher Vocational Schools Based on Training in High-Caliber Professional Accountants
}

\author{
Shiye Yuan \\ Zhongshan Vocational College \\ Nanjing, China \\ yuanfaye24@gmail.com
}

\author{
Yi Lou \\ Hohai University \\ Nanjing, China \\ ly0921ly@163.com
}

\begin{abstract}
Along with the changes in global economic landscape and acceleration of knowledge update cycle, different disciplines become interrelated and economic entity is diversified. Accounting and social economy is closely connected, since accounting talents playing a vital role on healthy development of the national economy. Requirement for accountants' professional quality becomes higher than ever, so the traditional education model in higher vocational college is not suitable for current society. This paper analyses the problem existed in current model from several aspects, such as talents training target, curriculum, teaching methods and teaching staff. Next, we propose several ideas in order to enhance the development of accounting education model in higher vocational schools. Finally, it turns out that the reform of accounting education model in higher vocational colleges is a systematic project.
\end{abstract}

Keywords- high-quality; professionalization; higher vocational colleges; Accounting Education; Reform of Education

\section{INTRODUCTION}

In recent years, the accounting education in China grew rapidly, which has been well-known around the world. From the perspective of education scale, there were more than one million and four hundred college students majored in accounting in the year 2012, about 1447002 students. There is a dramatic increase of 19.94 percent, compared with the number in 2011. From the perspective of education hierarchy, 851470 students were studying accounting in higher vocational college in 2012. The proportion that accounts for $58.84 \%$ of all accounting majored college students. The data was 5.69\% higher that the number in 2011. In addition, 39.76\% college students were undergraduates majored in accounting, around 575261 students. Compared with 2011, it showed a $12.88 \%$ increase. There were 19205 postgraduates who also chose accounting as their specialty in 2012. It also showed a $20.87 \%$ raise than previous year. Moreover, 1066 PHDs picked accounting as their major research direction in 2012, which increased $2.7 \%$ from 2011. Therefore, the educational scale in accounting major around colleges was significantly increase. Meanwhile, according to the data above, $60 \%$ of the accounting majored students were studying in higher vocational colleges. Since higher vocational education of accounting is the foundation of college accounting education, the statistical result indicates that study on higher vocational college accounting education model reform would impact the development of accounting major in college significantly.
Along with the development of technology and social economy, both requirement of companies and the adjustment of accounting standard results in the reform of Accounting Education Mode by current accounting education circle. Under the circumstances, this paper studies that how the accounting education mode should be reformed to achieve the purpose of cultivating high-quality and professional accounting talents. This study turns to give some useful advice to China's education for accounting in the higher education stage.

\section{THE INNOVATION IN TALENT CULTIVATION OBJECTIVES}

The objective of personnel cultivation represents the fundamental philosophy of talent development in higher vocational colleges, which directly relates to sustainable growth of the discipline. Pan Yushuang (2009) indicates that, the purpose of accounting education for higher vocational college students, undergraduates, and postgraduates is different. Training students' practical skills should be the primary goal for education in vocational colleges. However, the education of the undergraduates has to emphasis on scholars' comprehensive quality; for masters and PHDs, ability to do academic research is the most important. Since different levels of education has different requirement for talent training, vocational colleges have to focus on the change of accounting knowledge and needs of the developing society, so that their graduates meet the employer's requirements for staff. As an important part of China's accounting education, accounting education in vocational colleges should be both in a high level and professional. However, currently, the students from vocational colleges are taught more theoretical knowledge than occupational skills. Therefore, the education in vocational college is similar to what in other level of education. It cannot meet the requirement for High Vocational Education that "undertake the task of bringing up a high quality and high technological experts which meet the need of the production, construction, administration and service.”

There are three reasons leads to the problem.

A. From the Perspective of the Development of Technology, Intersection and Synthesis of Academic Branches Are Important Tendency for Subject Development

In the professional field of accounting, the situation has already significantly influenced the education, because some 
problems cannot be solved by knowledge from single independent subject. If accounting major students have no idea about the subjects that correlated with their major, such as economics, finance, management and other disciplines, they are not able to solve the comprehensive problem. Therefore, the technical personnel who graduated from current vocational college is not suitable for employers' need of staffs.

\section{B. From the Perspective of Student Resources, Generally Students from Vocational College Have Worse Learning Ability and Habits than Undergraduates}

It perhaps because they have the lowest score in college entry exam; that is, they perform not so well in previous stage of study. For this reason, it is better for vocational colleges to develop practical accounting talents. If most vocational colleges in China simply use the training program from university who has accounting major and ignore the difference between vocational college students and undergraduates, accounting practical skills of graduates from vocational colleges will not be acceptable for employers currently.

\section{From the Perspective of Social Demand, Accounting}

Talents Are in Short Supply, Especially Those Receiving

High Level Education and Having Good Practical Skills

Due to the stage of vocational college, high level accounting professionals are improbable to be trained in vocational college; thus the primary goal for these colleges is to develop practical accounting talents. Actually, most vocational colleges attach more importance to "professional education" than "high-quality practical education". As a result, although most graduates from vocational school have accounting practical skills, they are not able to analyze and deal with professional difficulties relates to accounting. In addition, their lacking of humanistic and professional quality cannot meet the requirements of society at present.

Conclusively, along with the development of knowledge economy, higher vocational colleges have to change their ideas of training accounting talents so that the education will keep up with the changing accounting knowledge. Integration of crosscurricular interests has to be take into consideration. The training quality will be higher if students take both accounting and other relative courses during their campus life. As vocational education has to be both high level and practical, training accounting talents who have comprehensive vocational ability and quality, suitable for working at first line of production, construction, service and management should be the objective of personnel cultivation in vocational college. Specialized in accounting major, the subject has two closely related parts, theory and practice. The reform of training mode in higher vocational college has to focus on the talents suitable for working in middle and small-sized enterprises. The graduates has to have good career morality and be skillful at accounting practice.

\section{THE REFORM OF CURRICULUM}

Currently, most accounting education in vocational colleges pays too much attention to discipline system's systematization and completeness. In other words, the school lay emphasis on teaching of techniques rather than inspiring innovation; theoretical knowledge rather than practical training; technique rather than quality. From the perspective of students' all-round development, neither current stage of accounting education nor practical skill training is not enough for their social development. Therefore, courses that enhance students to form better study and working habit should be added to the curriculum so that the future graduates will become professional and moral accountants.

There are several problems existing in recent vocational college accounting curriculum.

\section{A. Pay Too Much Attention on Theoretical Professional Courses}

The schools normally use the utilitarian oriented course choosing system. Besides, corresponding courses of occupational ethics and regulations for accounting are not involved in the curriculum

\section{B. Students' Development of Operating Skill and Creativity Are Limited}

It is so common that teaching program in school remain the same in several years, which indicates that training objectives and teaching program are not oriented by social demand.

\section{Students Are not Inspired to Think by Themselves.}

They are not able to turn theoretical knowledge into practical action. The problems that they could handle are the ones same as what they were taught in class. Once the problem changes a bit, the graduates would feel quite helpless and do not know how to solve it.

Faced with these problems, "high-quality and professionalization" should be the goal for the reform of accounting curriculum in vocational colleges. An outstanding curriculum system has to unite basic literacy, theoretical knowledge with professional skill courses. A curriculum system has been designed as follows in FIGURE 1, 


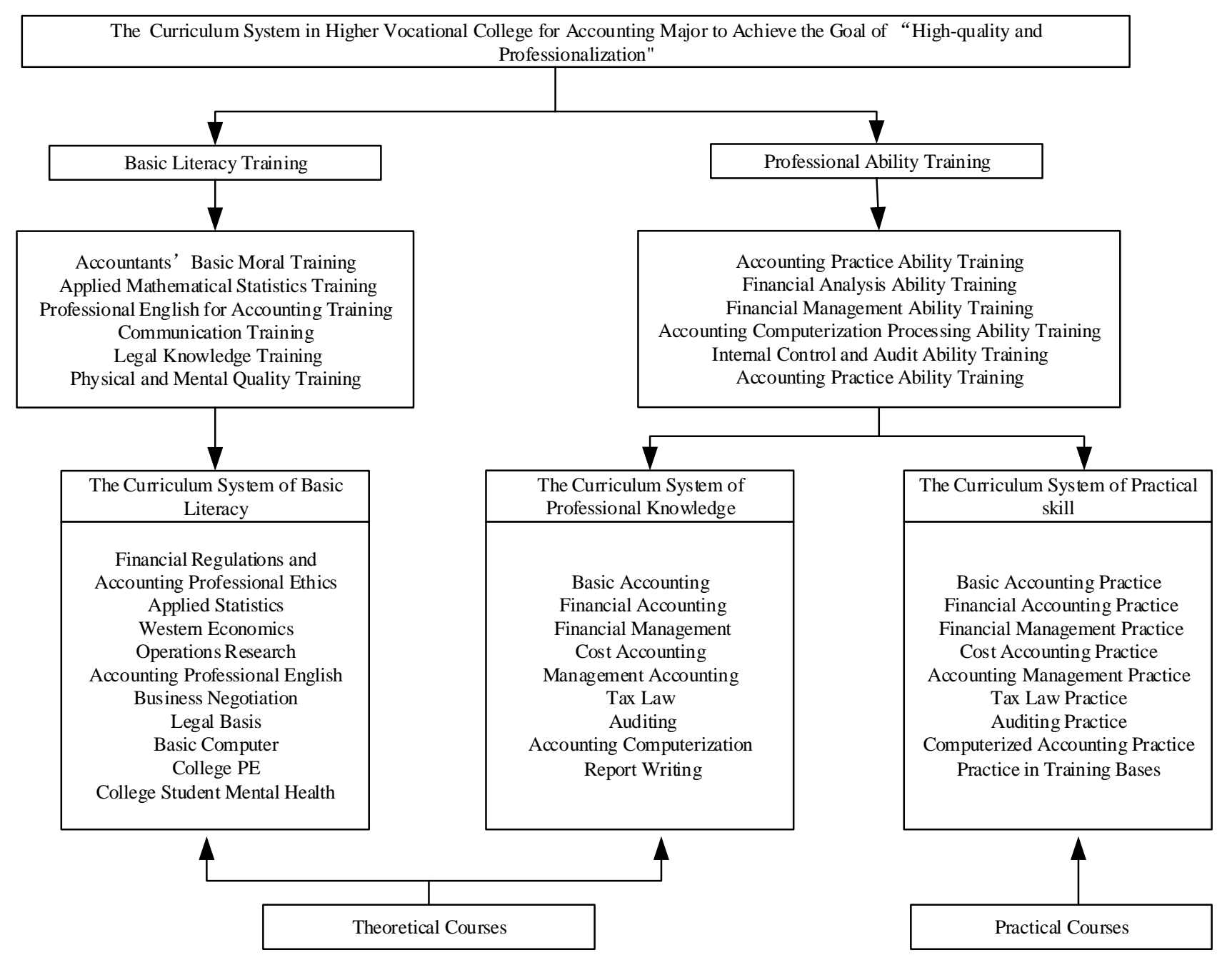

\section{FIGURE 1 THE CURRICULUM SYSTEM IN HIGHER VOCATIONAL COLLEGE FOR ACCOUNTING MAJOR TO ACHIEVE THE GOAL OF "HIGH-QUALITY AND PROFESSIONALIZATION"}

According to the figure above, the core content of the "high-quality and professionalization" curriculum system is the training of basic literary and professional abilities. In other words, there are six aspects involved in basic literary training, such as accountants' basic moral training, applied mathematical statistics training, professional English for accounting training, communication training, legal knowledge training, and physical and mental quality training; the professional ability training includes accounting practice ability training, financial analysis ability training, financial management ability training, accounting computerization processing ability training, internal control and audit ability training, and accounting practice ability training. The purpose of designing the system is to construct the students' fundamental values and structure of knowledge. Thus, the graduates will give full play to their professional abilities. In this case, the curriculum system of basic literacy is formed by eleven courses, for example, financial regulations and accounting professional ethics, applied statistics, western economics, operations research, accounting professional English, business negotiation, legal basis, basic computer, college PE, and college student mental health. Meanwhile, there are two features comprise the professional ability system, the curriculum system of professional knowledge and the curriculum system of practical skill. The courses of professional knowledge are basic accounting, financial accounting, financial management, cost accounting, management accounting, tax law, auditing, accounting computerization, and report writing. In addition, the practical skill courses are basic accounting practice, financial accounting practice, financial management practice, cost accounting practice, accounting management practice, tax law practice, auditing practice, computerized accounting practice, and practice in training bases.

In summary, basic literary training courses and professional ability training courses form the theoretical course system in college; meanwhile, the practical courses system is formed by professional ability training courses. Based on resources in college currently, it is better for the accounting talent management department to reform the curriculum system in 
higher vocational college and arrange the courses appropriately in order to achieve the goal of training the "high-quality and professional” graduates. Therefore, the graduates will meet the social demand.

\section{The Reform Of TEACHING Method}

As a highly technical subject, the practical parts play an important role in accounting education. However, most courses in resent vocational college are theoretical ones so that classes for practical courses are limited. Consequently, the circumstance that the students knew but not understand the knowledge becomes so common. In other words, the students not only know little about their theoretical knowledge, but also cannot combine theory with practice.

There are two problems existed in vocational colleges' accounting educational method,

\section{A. Problems Existed in the Teaching Methods of Accounting Theoretical Knowledge}

Concept analysis, comparative method, and case analysis are wildly used in the study of theoretical knowledge. It seems that these methods are suitable for all the theoretical teaching link; nevertheless, these method do not have good practical effect. For instance, some teachers from vocational schools simply use the cases from textbooks for Certified Public Accountant in their classes, which are obviously not suitable for vocational school students.

\section{B. Problem Existed in the Teaching Methods of Accounting Practical Skills}

On accounting practical training, the teachers usually combine explaining and practicing. This method emphasizes the balance of teaching and practice. Thus, as a matter of fact, the off-campus practice bases are not enough for the large amount of students. Therefore, the practical training has to do at school which largely reduce the usefulness of training courses, since the cases chosen in class are far from reality. What is worse, as teachers' lack of specific work experience, the class for practical skill training would probably turns into students' Self-study courses. A large amount of students will copy homework from others. As a result, the quality of education will reduce and students will develop bad habits. This kind of accounting major graduates is definitely not the employers needed.

Aiming at the problems above, accounting teaching methods in higher vocational colleges can be reformed from the following two aspects,

From the aspect of theory teaching, instead of leading by teacher, students should have their own ideas. It is better for the teacher to use the heuristic didactics. The main role for teachers is guide. They have to teach the students how to think rather than control the whole teaching process, because students are the protagonist the teaching.

From the aspect of practical skill training, since teaching resources are limited, the accounting practical training has to be taught in school in most times. Therefore, scene simulation method can be applied in class; that is, set the specific position and compile a set of training project based on actual realities for students, so that they will face the actual accounting problems in simulation environment. In that case, students will be interested in accounting practice. Moreover, accounting vouchers, books and statements enhance students' understanding of accountants' responsibility. After the scenario simulation training, students know how to link theory to practice, which will be beneficial to their accounting career.

\section{CONCLUSIONS}

The reform of accounting education model in higher vocational colleges is a systematic project, which includes the adjustment among talents training target, curriculum, teaching methods and teaching staff. Therefore, the student taught by the model will adapt to the development of social economy. Firstly, this paper analyses the problems existed in current higher vocational college accounting education model. Then set the goal of "high-quality and professional" for the reform of accounting curriculum in vocational colleges. Next, from the perspective of curriculum setting, the curriculum system is formed by theoretical and practical courses. Finally, from the aspect of adjustment of theoretical and practical teaching method reform, scientific principles for talent cultivation and teaching resources in vocational colleges should be taken into consideration. Teaching students at different levels and adding more practice outside are two acceptable advice for the vocational colleges currently. The adjustment of education mode aims to drive students to learn actively in order to achieve the goal of accounting education mode reformation.

\section{REFERENCES}

[1] P. E. Madsen. "How Standardized is accounting?" The Accounting Review., 2011, 86(5), pp. 1679-1708.

[2] CFA Institute , Financial Reporting and Analysis, Level 1. Volume 3, 2012, pp. 94-109.

[3] M. Liguori, and I. Steccolini, "Accounting Change: explaining the outcomes, interpreting the process," Accounting, Auditing and Accountability, 2012, 25(1), pp. 27-70.

[4] C. S. Warren, J. M. Reeve, and P. E. Fess, Financial Accounting, 9th ed., Higher Education Press, 2005.

[5] Accounting Education Change Commission(AECC), "Objectives of education for accountants: position statement No.1," Issues in Accounting Education, 1990, 5(2), pp. 307-312 .

[6] M. Kavanagh, and L. Drennan, "What skills and attribute does an accounting graduate need? evidence from student perceptions and employer expectations," Accounting and Finance, 2008(48), pp. 279300 .

[7] L. A. Nikolai, and J. D. Bazley, Intermediate Accounting 9ed, Thomson, 2005.

[8] L. Zhao, "The professional morality education of vocational college students majoring in computerized accounting in Xinjiang-basic on Bayin Guoleng vocational and technical college,” Shihezi University, 2013.

[9] C. Zhou, "Research on the accounting teachers' professional development in vocational college under the implement of 'new guidelines',

[10] W. Mao, "Some advice of present situation and reform of accounting education in higher vocational colleges,” Higher Education Forum, 2009, 2(2), pp. 106-108, 112.

[11] X. Yang, "Problems and countermeasures for accounting education in higher vocational colleges,” China Education Innovation Herald, 2012, No.29, pp. 9. 